ACTA VET. BRNO, 58, 1989: 261-272

\title{
DIFFERENCES IN THE STROMA ARRANGEMENT OF LYMPHOMAS OF MAREK'S DISEASE AND LYMPHOID LEUKOSIS IN POULTRY
}

\section{P. NEUHYBEL}

Department of Pathological Morphology and Parasitology, University of Veterinary Science, 61242 Brno

Received February 25, 1988

\begin{abstract}
Neuhybel P.: Differences in the stroma arrangement of lymphomas of Marek's disease and lymphoid leukosis in poultry. Acta vet. Brno, 58, 1989: $261-272$.

Thirty one-day-old chicks were infected with the virus of Marek's disease (MD), 30 chicks with the supernatant from the tissue culture of the clone LSCC-H32 producing viruses of lymphoid leukosis (LL) and 10 chicks served as controls. The lymphomas were histologically examined by staining with hematoxylin-eosin according to Van Gieson and Gomori, and with methylene green pyronine for RNA. Smear impressions from the sectioned surface of the compact tumor can also be used for orientation examinations. Collagen fibres do not contribute to the formation of lymphomas in MD and neither in LL. In MD, the reticular fibres form a dense network which is diffusely disseminated into the surrounding tissue, while in LL the lymphomas are sharply defined by the argyrophilic capsule with virtually no reticular fibres inside. The cell homogenate of MD lymphomas is considerably pleomorphic with small and medium-sized lymphocytes predominating. As concerns the cellular structure, the LL tumors consist of larger monomorphic blast-like cells with an activized nucleolus and pyroninophilic cytoplasm. For a more differentiated diagnosis of $\mathrm{MD}$ and $\mathrm{LL}$ we must take into account, besides the age of the affected birds, the incidence of the diseases in $\%$, neural lesions, proliferation in the bursa and changes on the skin, also the participation of the individual cellular elements with regard to the content of RNA, character of growth and the structure of arrangement of reticular fibres.
\end{abstract}

Marek's disease, lymphoid leukosis of poultry, reticular fibres, histopathology

Tumorous diseases of poultry represent serious problems not only from the economic and veterinary-hygienic, but also general biological and medical points of view. Biggs (1975) reported that Marek's disease (MD), for example, can serve as a convenient model system for knowledge on the oncogenic effect of herpes viruses and diseases which they evoke. Kožušník (1987) studied the occurrence of diseases in poultry in 1986 and stated that acute MD remains to be a permanent problem 
and that in spite of vaccinations performed, the losses in some flocks in the CSSR amounted to $20 \%$ and even more. Lojda (1986) reported that MD contributed to $52 \%$ and $48 \%$ of losses of poultry in large-scale breeds and in flocks of private farms, respectively, whereas LL caused only $3 \%$ of mortality in large-scale flocks; his investigations were carried out in 1975-1985. As early as in 1973, Lešník et al. (1973) drew attention to the fact that differential diagnosis between MD nad LL had not been elaborated sufficiently, so that when evaluating the results of losses caused by $M D$, the contribution of $L L$ could be indefinable. In spite of the fact that the problem of differential diagnosis of MD and LL had recently been repeatedly set forth, especially with respect to vaccination against $M D$, its topical importance continues; what has been proved by Lojda and Böhm (1984) who presented interesting practical findings on the changing picture of MD and LL over the past years. With MD the occurrence of the so-called "classical neuritides" has decreased and, on the contrary, the incidence of tumors on organs has increased and the pathological-morphological picture of both diseases (under certain circumstances and at a certain age) can merge making differential diagnosis difficult. One of the possibilities, which has been somewhat neglected in CSSR in connection with the advancement of immunological methods, is a more detailed evaluation of the use of histopathological methods of staining. Since the originator of MD is the DNA herpes virus and of avian leukosis the RNA retrovirus, the histopathological differentiation of some forms is very complicated. Difficulties arise when differentiating acute (i.e. visceral) forms of MD and LL, whereas other forms can be differentiated.

The aim of the present study was to examine the suitability and usability of some histopathological methods of staining (according to Van Gieson, Gomori; methylene green pyronine) for the differentiation of lymphomas in MD and LL. Main attention was devoted to the following: character of growth, structure and configuration of the stroma, shape, size and participation of lymphoid cells, and the content of RNA in their nucleolus and in the cytoplasm.

\section{Materials and Methods}

Birds divided into the following three groups were used for pathological and morphological examinations:

1st group - 30 chicks infected with the MD virus

2nd group - 30 chicks with experimentally induced LL

3rd group - 10 untreated control chicks

One-day-old chicks of the HX-SL laying hybrid were used for the experiment. Chicks of the 1st group were infected on the first day after hatching with a field isolate of the MD virus which had been isolated from the reproductive laying breed affected with the acute form of MD at the age of 20 weeks. Each chick was inoculated with $0.2 \mathrm{ml}$ of the skin homogenate i.m. into the musculature.

One-day-old chicks of the 2nd group were infected with the supernatant from the tissue culture of the LSCC-H32 clone which produces viruses of avian leukosis of the A and B subgroups inducing LL in non-inoculated chicks within 22 weeks after infection (Kaaden et al. 1982). The chicks were infected subcutaneously with a dose of $0.5 \mathrm{ml}$. On the second day the chicks were given an i.m. dose of $0.2 \mathrm{ml}$ of the vaccine against MD - MARVAK Bioveta Nitra.

Chicks of the 1st group were exsanguinated and dissected at the age of 12-14 weeks, chicks of the 2nd group and control chicks at 21-37 weeks of age. Samples of the following organs were taken and subjected to histopathological examinations: liver, spleen, glandular stomach, kidney, heart, ischiadic nerves, pancreas, thymus, 
bursa of Fabricius, lungs, testes (ovaries) and intestine. The samples were fixed in $96 \%$ ethyl alcohol which was substituted with $70 \%$ ethyl alcohol after 4 hours so that staining with methylene green pyronine could be done. After fixation, the samples were embedded in paraffin using the autotechnicon routine method; on a sliding microtome paraffin sections were cut and stained with hematoxylin eosin according to Van Gieson for evidence of collagenous fibres, according to Gomori for evidence of reticular fibres (Wolf 1954), and with methylene green pyronine for evidence of RNA in the nucleolus and cytoplasm (Pearse 1960). The sections were mounted into Canada balsam and microscopically evaluated.

The macroscopically visible tumors were cut, a cover glass was placed to the cut surface, slightly slipped down and immediately immersed for 2 minutes into $96 \%$ ethyl alcohol; they were then stained with hematoxylin-eosin, methylene green pyronine (Siccardi and Burmester 1970) and according to Giemsa-Romanowsky (Wolf 1954).

\section{Results}

The method of impressions proved to be suitable for the cytological differentiation of lymphoma cells, the advantage to histological sections being as follows: this method is quicker and simpler, there is no need of so many reagents and equipment

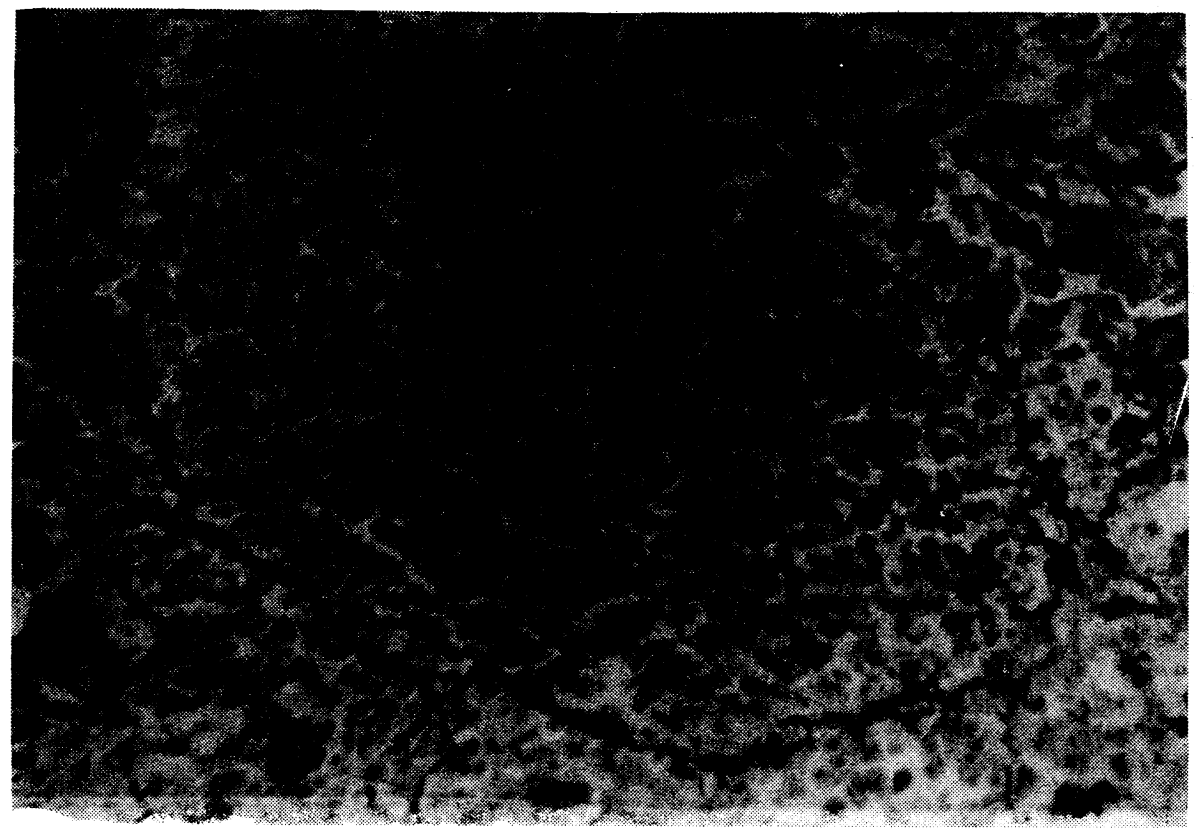

Fig. 1. Demarcation of the lymphoma in liver with reticular fibres in LL. Gomori, oc. 10, obj. 10

and it gives a clear definition of cellular morphology. However, the result of staining is greatly dependent on the quality of the impressions, they must be fresh, taken from the mass of the tumor, and they must be straight and fixed while still moist.

Staining with methylene green pyronine shows the amount of RNA in the nucleolus and cytoplasm, but the disadvantage of this method is that the results are very variable and dependent on the material, quality of the smear and on fixation. 
For quick orientation, the results of macroscopical and microscopical examinations with regard to the occurrence of lymphoid proliferation, are given in Fig. 9 and 10.

Within the first fortnight, 5 chicks infected with the leukosis virus died, so the tables include 25 chicks only.

Of the total amount of 30 chicks infected with MD and LL, the nervi ischiadici were affected in 9 and 0 chick, respectively. Three chicks infected with MD manifested enlargement of the bursa of Fabricius; histologically, in 12 chicks it was infiltration of the interstitium with pleomorphic lymphoid cells.

In the group infested with LL, a visible enlargement of the bursa was observed in 13 chicks, but we must take into account the fact that at the age when the chicks were examined the bursa was involuting in the control chicks. Histologically, in 14 chicks it was an intrafollicular expansive proliferation of large lymphoid cells. The interfollicular stroma remained unchanged. The difference between MD and LL thus lies in the localization of the tumors in the bursa.

Staining of the histological sections according to Van Gieson showed that collagenous fibres do not contribute to the construction of the stroma of lymphomas in MD and neither in LL.

Staining according to Gomori showed an expressive argyrophilia of lymphomas in $\mathrm{MD}$ when the reticular fibres formed a dense network among the proliferating lymphoid cells, diffusely disseminating and disappearing in the surrounding tissue. The same picture was repeated virtually in all the organs. On the other hand, in LL the lymphoid foci were as if demarcated by the capsule formed by the reticular fibres, however, hardly any argyrophilia was observed within the foci.

Differences in the growth and proliferation of tumors could be observed already when staining with hematoxylin-eosin. In MD, growth was greatly infiltrative so that small districts of the original tissue remained in the large masses of lymphoid

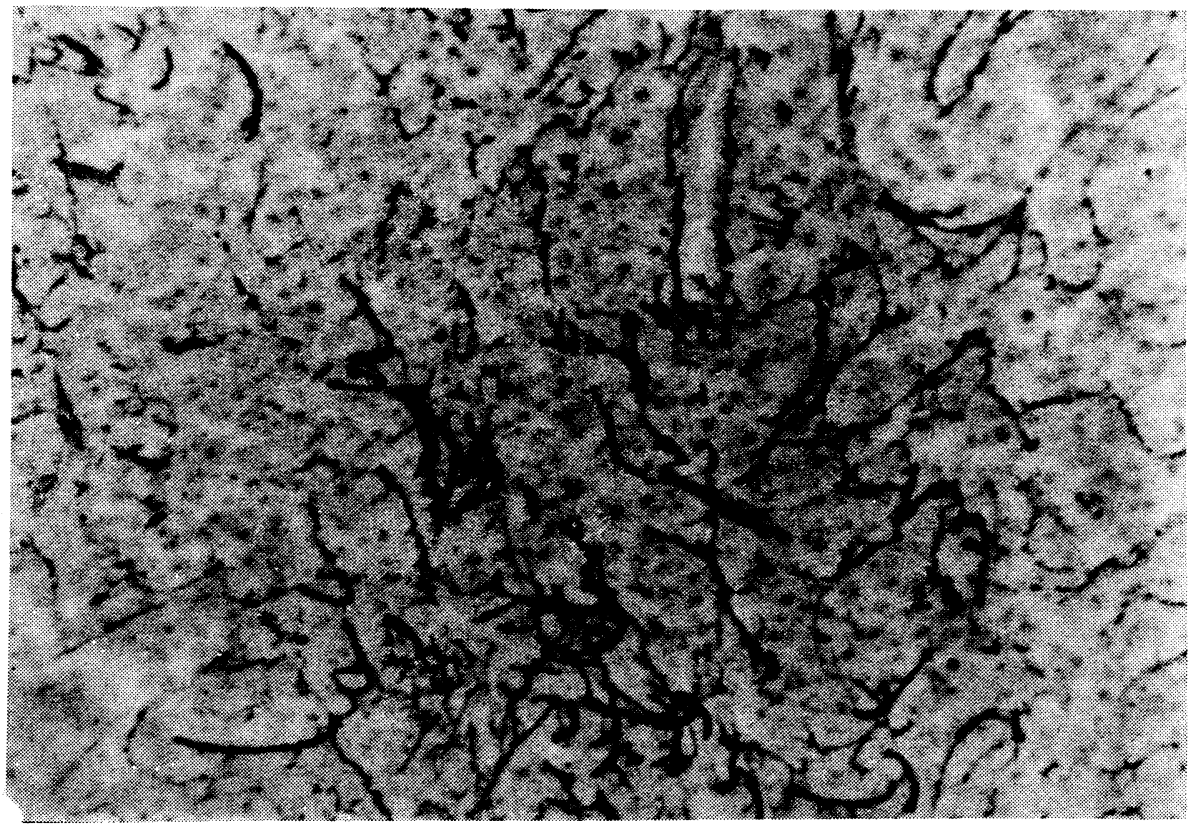

Fig. 2. Marked diffuse argyrophilia of reticular fibres within the lymphoma in liver in MD. Gomori, oc. 10, obj. 10 


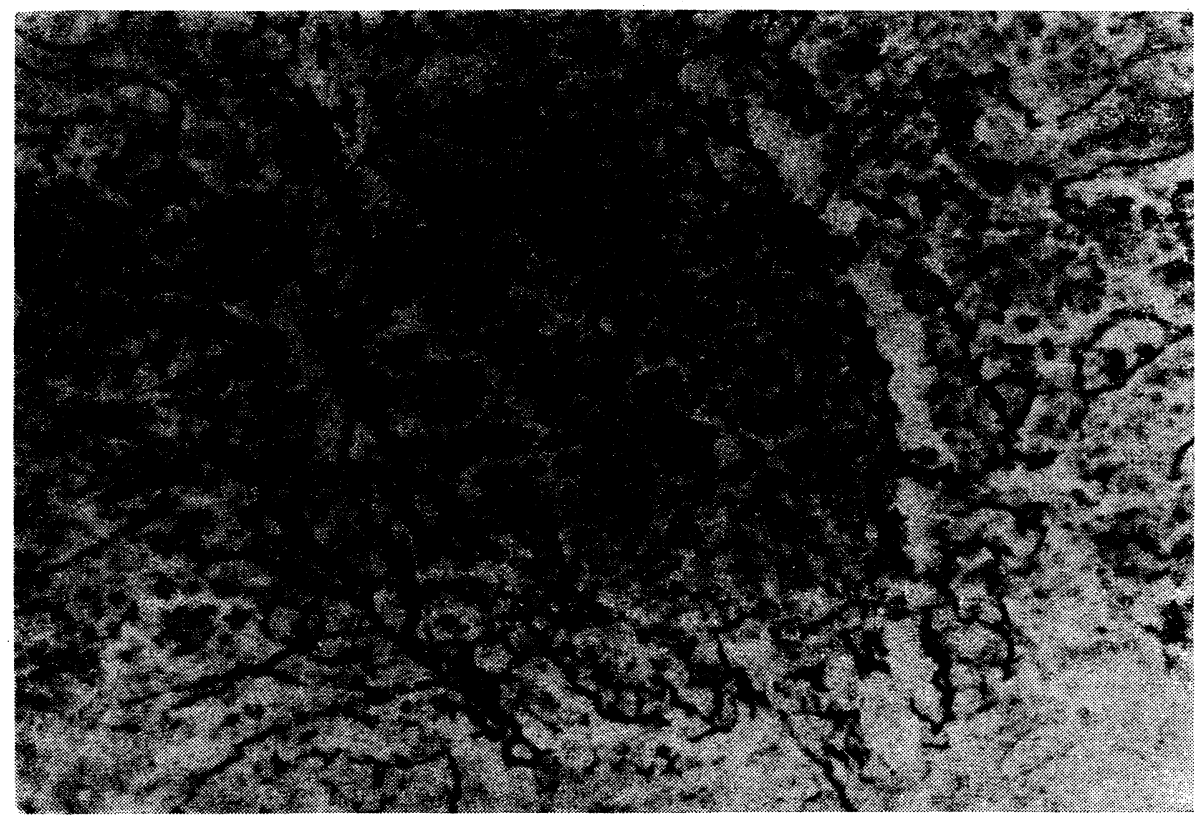

Fig. 3. Demarcation of lymphoma with reticular fibres in liver in LL. Gomori, oc. 10, obj. 10

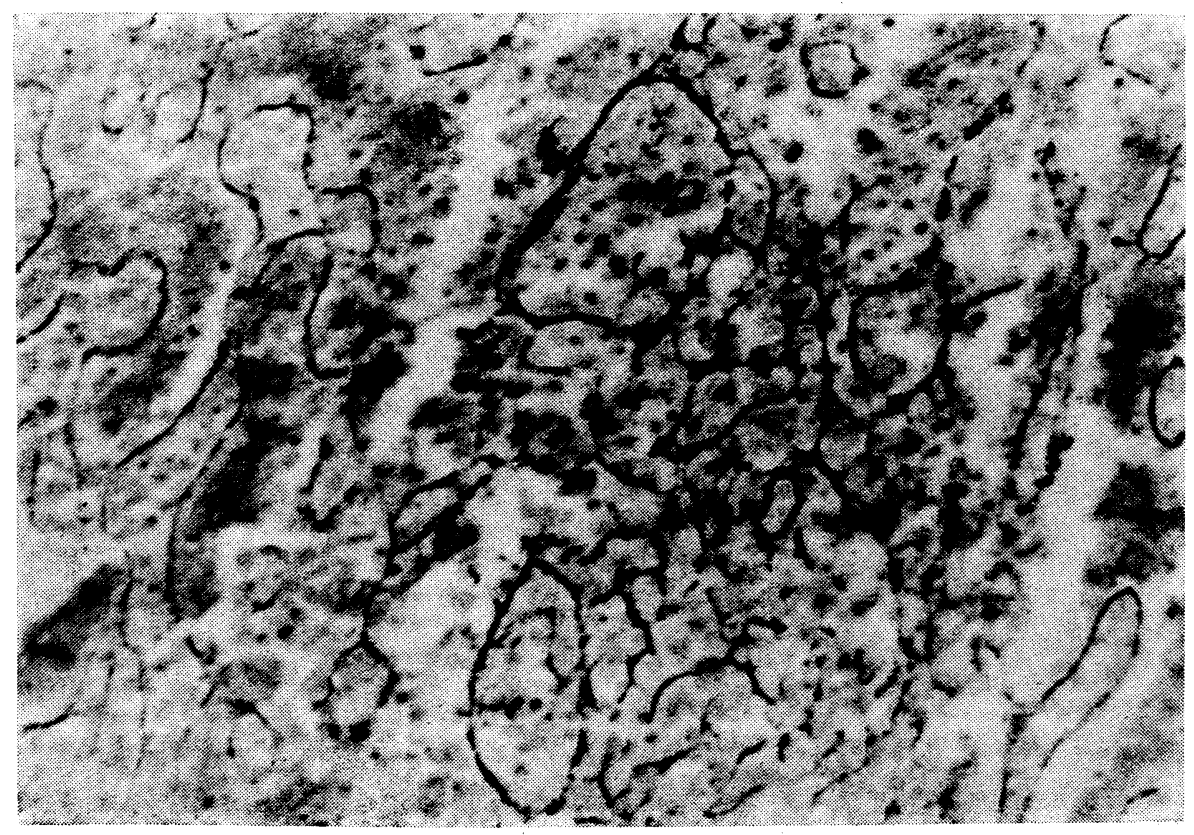

Fig. 4. Network of reticular fibres within the lymphoma in liver in MD. Gomori, oc. 10, obj. 10 


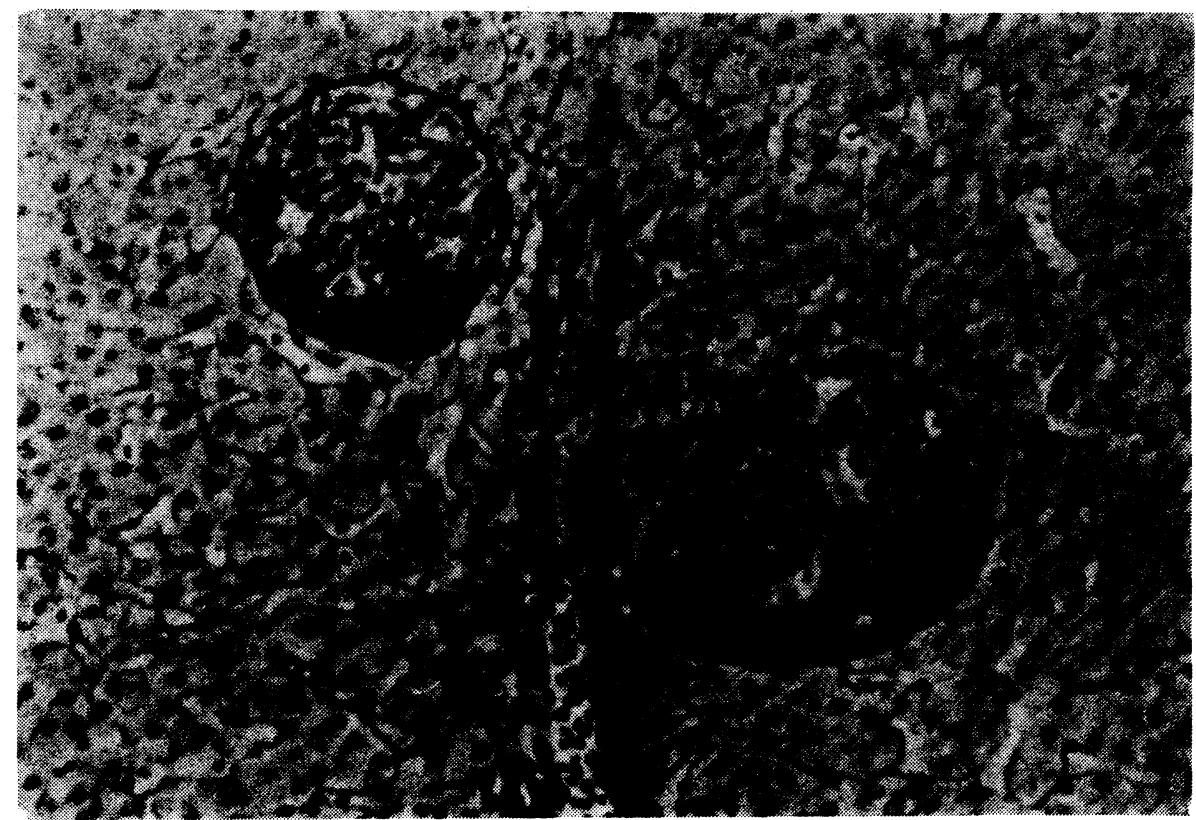

Fig. 5. Two small lymphomas with argyrophilic demarcation in livre in LL. Gomori, oc. 10, obj. 10

cells, whereas in LL, growth was rather focal, follicular and demarcated. This phenomenon was the most typical in the liver parenchyma, lungs and heart, while in the kidneys remains of draining ducts remained in larger foci in LL.

Differences between the two diseases appeared also in the localization of initial changes, when the lymphoid proliferations in MD were usually oriented to the perivascular areas, what was not true with LL. In the sexual organs of the chicks affected with MD, lymphoid proliferations in the interstitium were observed both in the testes (in 10 chicks) and in the ovaries (in 12 chicks), while the gonads were not affected in LL.

The glandular stomach of the MD-infected chicks was affected in 15 chicks, in 7 of them the wall was greatly thickened so that the lumen was considerably reduced. In LL, only microscopically follicular foci in the mucous membrane of 13 chicks were observed.

The cellular structure of the lymphomas is considered to be a very important differentiation character. Changes between MD and $\mathrm{LL}$ in the individual organs did not differ very much in their cellular structure. The lymphoid accumulation for MD was characterized by a strong pleomorphy. Lymphoid cells predominated, they were differentiated, of various shape and size, from small lymphocytes to large, so-called blast-like cells. When staining with methylene green pyronine, the presence of RNA in the nucleolus and in the cytoplasm in polyribosomes appeared as red in colour. However, these cells in MD were in minority. Some of these pyroninophilic cells in the cytoplasm contained a great vacuole or several smaller ones. These cells corresponded with the so-called Marek's disease cells described. In the cell homogenate also activized reticular cells with long projections appeared and sometimes heterophilic and eosinophilic granulocytes. Very frequent were also manifestations of necrobioses in the individual cells, also appearing in foci. 


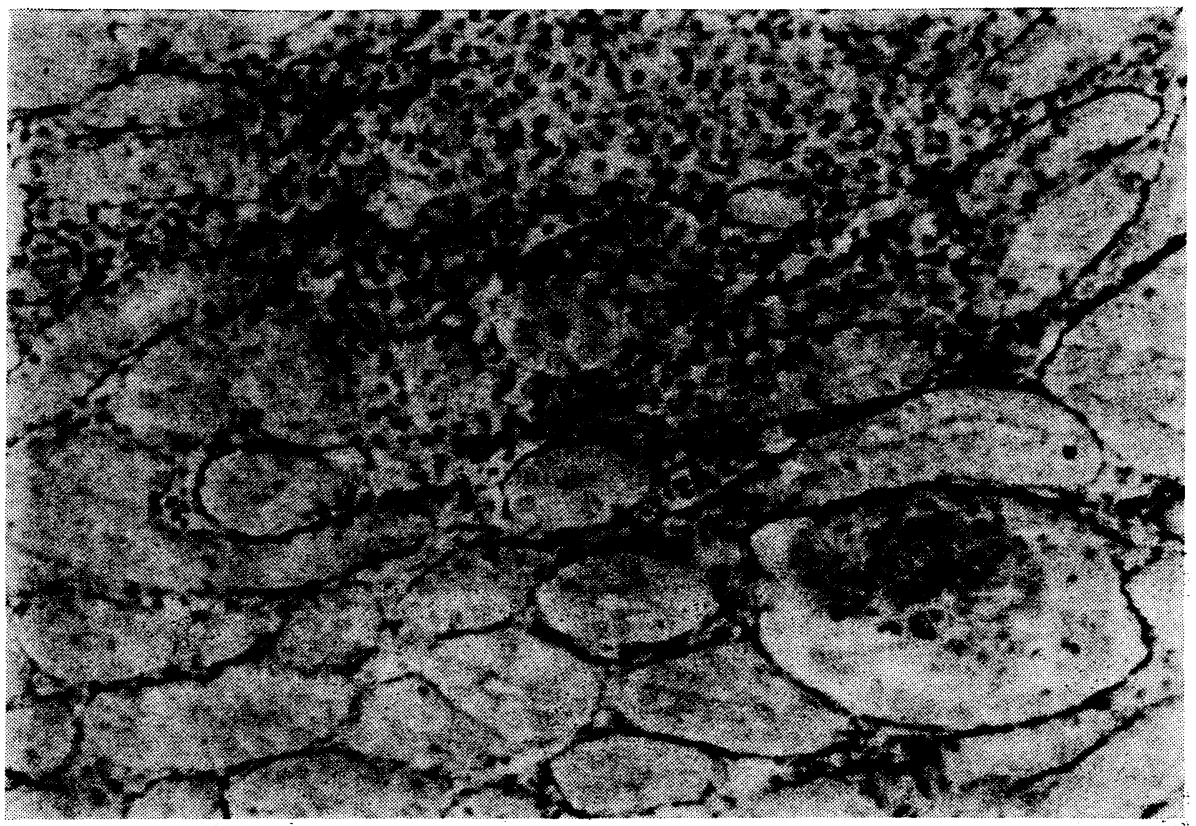

Fig. 6. Proliferation of lymphoid cells demarcated with reticular fibres in the pancreas in LL. Gomori, oc. 10, obj. 10

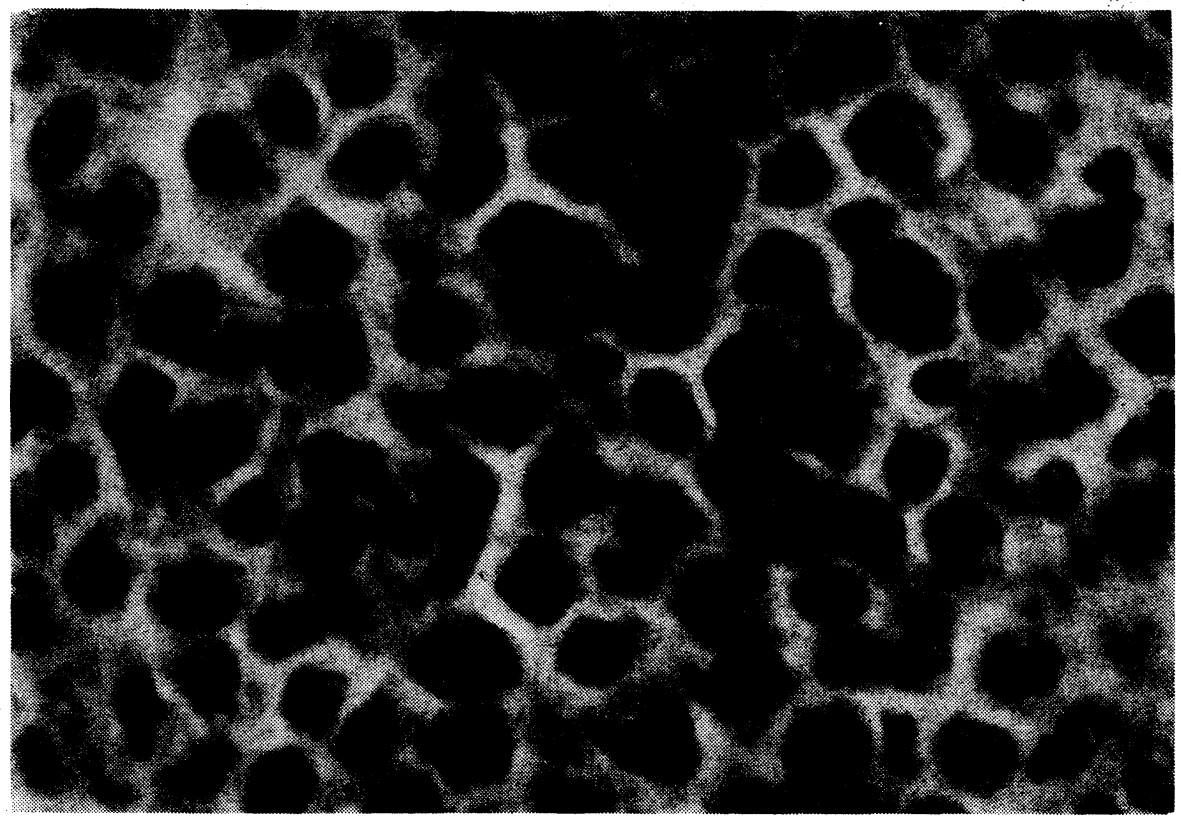

Fig. 7. Monomorphous character of lymphoid proliferation in liver in LL. The majority of cells have one or two distinct nucleoli. HE, oc. 10 , obj. 45 
In LL there appeared round or oval foci sharply demarcated from the surrounding tissue. The majority of lymphoid cells of the tumor were cells which could be classified as large lymphocytes and lymphoblasts. The cell homogenate was monomorphous. The uniformity of the cells was evident when stained with HE and with evidence for RNA when the absolute majority of cells showed distinct pyrinophilia of the nucleolus and of the cytoplasm.

\section{Discussion}

The great importance of differential diagnosis of MD and LL has been proved in some papers read at the conference on problems of health of the domestic fowl held in Nové Město na Moravě in 1987 (Benda et al. 1987). Benda (1984) reported that the supression of tumorous diseases cannot be performed without timely and

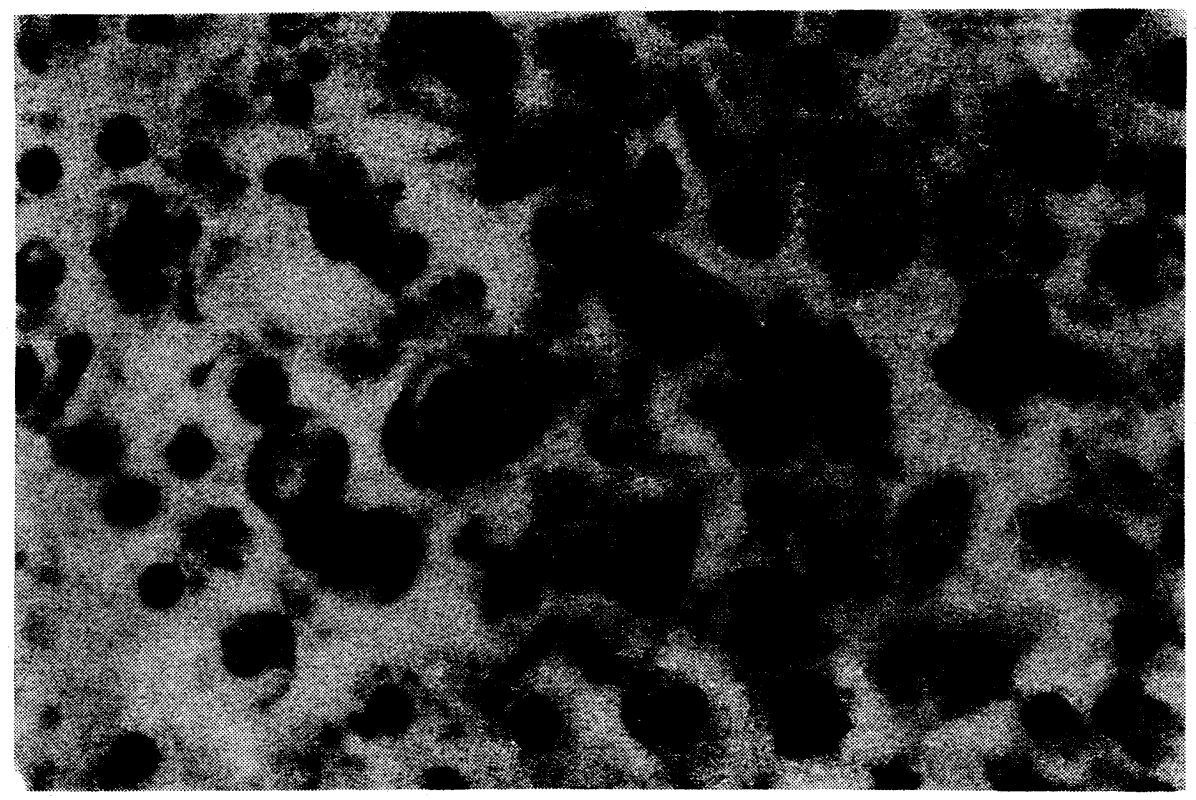

Fig. 8. Marked pleomorphy of the cellular infiltrate in the pancreas in MD. Van Gieson, oc. 10, obj. 45

accurate diagnosis. In hens, differential diagnosis of MD and LL are in the fore; so far it has usually been based on age, incidence in \%, clinical symptoms and macroscopical and histopathological findings. In many cases this extensive set of data is not sufficient for univocal determination of the cause of the disease or mortality, what would be necessary especially for understanding the so-called vaccination failure. Serological and virological examinations do not help either because tumor viruses are ubiquitous and the presence of antibodies is usually not associated with the manifestation of the disease.

Diagnostical difficulties occur mainly in the older age categories of hens (as a rule, of more than 16 weeks) what is generally accepted as the age possible for both diseases (Hofstad et al. 1978). This is the reason why the chicks of laying hybrids were used for the experiments. 


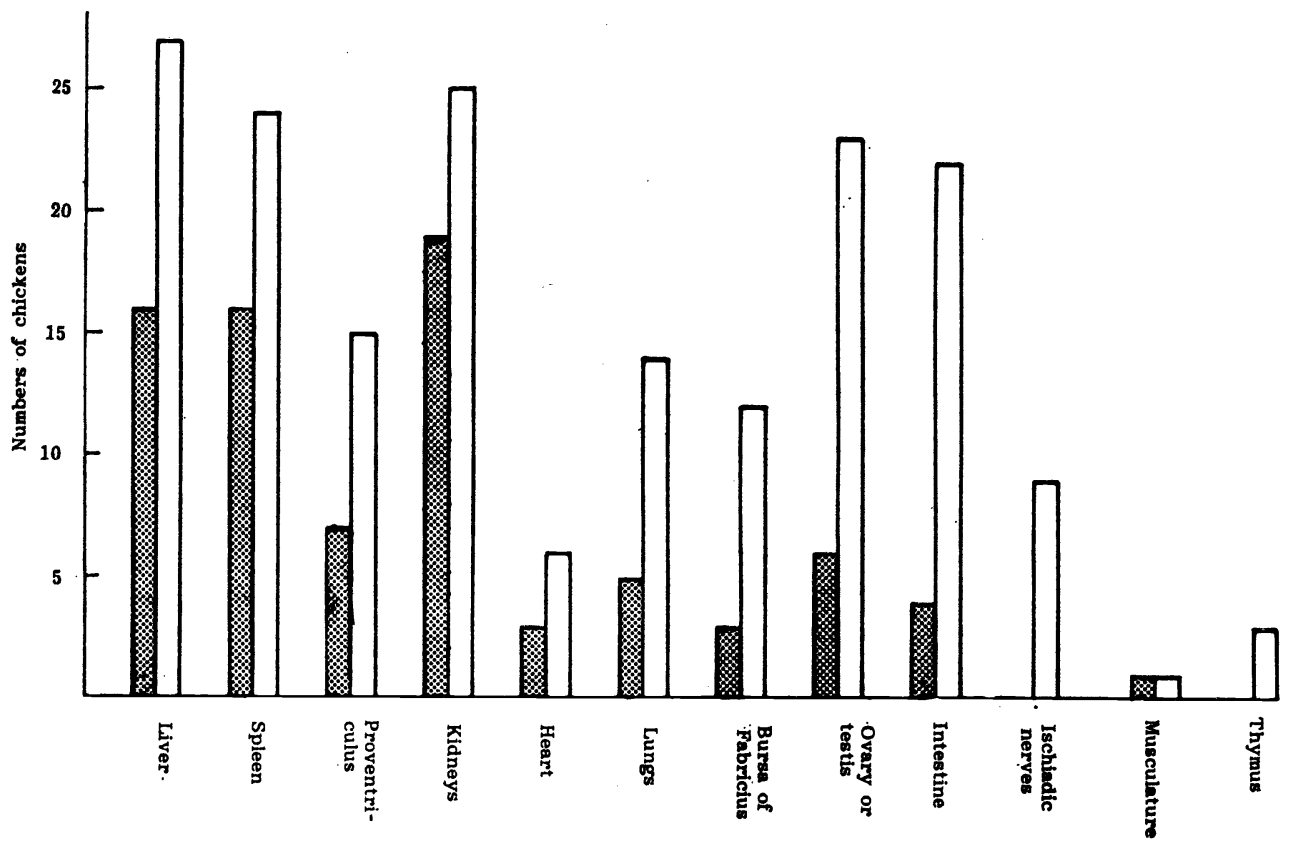

Fig. 9. Results of morphological examinations of chicks infected with the virus of MD (dotted columns - macroscopic changes, empty columns - microscopic changes).

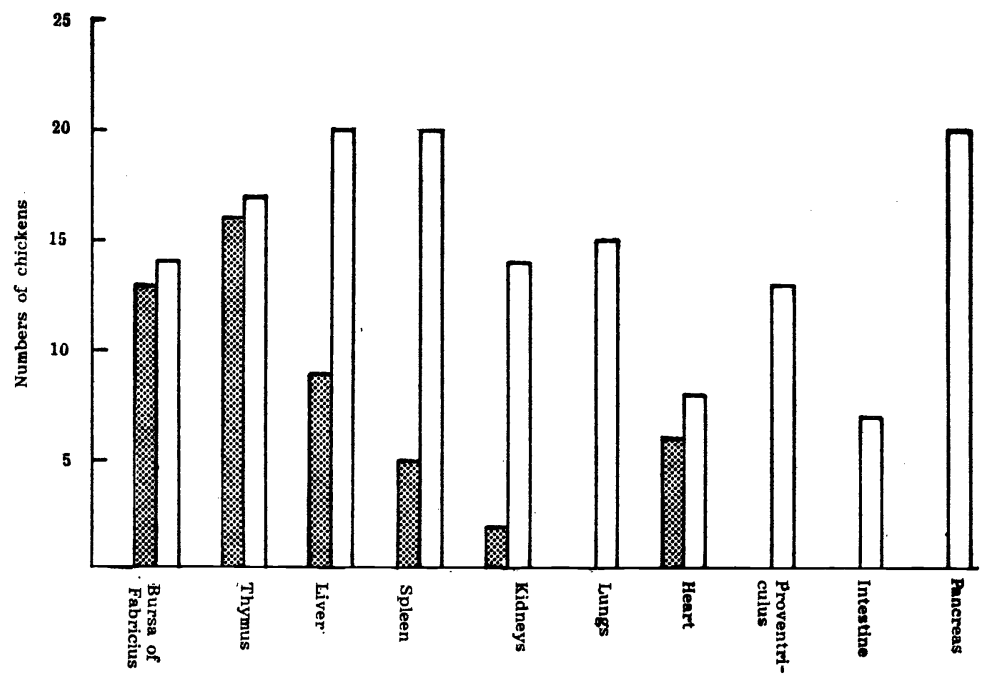

Fig. 10. Results of morphological examinations of chicks experimentally infected with supernatant from the tissue culture of the clone LSCC-H32. (For legend see Fig. 9.) 
Findings of lymphoid infiltrations in the ischiadic nerves are very important for MD diagnosis; however, they appeared in 9 chicks only. If neural lesions are absent, then it is necessary to observe other morphological criteria. Another character pathognomic for MD are changes on the skin which had not been the object of the present study and which had recently been studied in our laboratory by Halouzka (1981).

The differences in and localization of tumors in the bursa found by the author of the present study are in accordance with the findings of Siccardi and Burmester (1970) and Hofstad et al. (1978).

Yamamoto et al. (1972) and Maas (1974) also considered the differences in the arrangement of the newly formed reticular stroma of the lymphomas in MD and LL, what was investigated in the present study, to be pathognomic.

Findings of lymphoid proliferations in the interstitium of the gonads in MD and their absence in LL are also in accordance with data given in literature (Biggs 1975).

Differences in the cellular representation of the individual cells (small to large, so-called blast cells) are an important character of differentiation, even though the data on these cells lack uniformity in literature. Neuwirt et al. (1983) consider the blastic transformaticn as a change in the lymphocyte which accompanies the transformation of the cell which does not divide for a long time into a cell undergoing mitotic division. Blasts are sometimes indicated as immunoblasts or lymphoblasts (Bedná ŕ and Kulhánková 1984). According to Bier et al. (1984) a blast cell is the developmental stage of cells of the mesenchymatous tissue from which the terminal forms are differentiated: they are characterized by active metabolism and morphologically they are characterized by a nucleus with a more loosely arranged chromatin, large nucleolus and great amount of cytoplasm with numerous polyribosomes.

\section{Rozdílnosti v uspořádání stromatu lymfomů Markovy nemoci a lymfoidní leukózy drůbeže}

Bylo infikováno 30 jednodenních kuřat virem Markovy nemoci $(\mathrm{MN}), 30$ kuřat supernatantem z tkáňové kultury klonu LSCC-H32, která produkuje viry lymfoidní leukózy (LL) a 10 kuřat sloužilo jako kontrola. Vytvořené lymfomy byly vyšetřeny histologicky s použitím barvení hematoxylinem eosinem, podle Van Giesona, stříbření podle Gomoriho a methylzelení pyroninem k průkazu RNK. K orientačnímu vyšetření možno použí $\mathrm{i}$ otiskủ z řezné plochy kompaktního tumoru. Na tvorbě lymfomů se nepodílejí kolagenní vlákna ani u MN ani u LL. U MN vytvářejí retikulární vlákna hustou sítovinu, která difuzně mizí v okolní tkáni, zatímco u LL jsou lymfomy ostře ohraničeny argyrofilním pouzdrem, přičemž uvnitř se retikulární vlákna téměr̆ nevyskytují. Celulizát lymfomủ $M N$ je značně pleomorfní s převahou malých a středních lymfocytů. Buněčné složení tumorủ LL je tvořeno většími monomorfními blasty s aktivovaným jadérkem a pyroninofilní cytoplazmou. Při prohloubení diferenciální diagnostiky MN a LL je nutno brát $\mathrm{v}$ úvahu kromě stáří postižené drủbeže, incidence v \%, neurálních lézí, proliferací v burze a změn v kǔži, také zastoupení jednotlivých buněčných elementủ s ohledem na obsah RNK, charakter růstu a strukturu uspořádání retikulárních vláken. 


\section{Разность расположения стромы лимфом болезни Марека и лимфоидного лейкоза птицы}

Тридцать цыплят в суточном возрасте инфицировали вирусом болезни Марека (БМ), 30 цыплят - супернатантом из тканевой культуры клона LSCC-H32, продуцирующей вирусы лимфоидного лейкоза (ЛЛ) и 10 цыплят использовали в качестве контрольной группы. Образовавшиеся лимфомы иоследовали гистологически, окрашивая их гематоксилином эозином по Ван-Гиоону, серебрение проводили по Гомори и метилзеленой пиронином для определения РНК. Для ориентировочных иоследований можно использовать также оттиски от поверхности разреза компактной опухоли. В образовании лимфомов не участвуют коллагенные волокна ни в случае БМ, ни ЛЛ. У БН ретикулярные волокна образуют плотную сеть, диффузионно исчезающую в соседней ткани, между тем как у ЛЛ лимфомы четко ограничены аргирофильной сумкой, при этом ретикулярные волокна внутри почти не встречаются. Целлюлизат лимфомов БМ отличается значителыной плеоморфностью с преобладанием малых и средних лимфоцитов. Клеточный состав опухолей ЛЛ образован более крупными мономорфиыми бластами с активированным ядром и пиронинофильной цитоплазмой. Углубляя дифференциальную диагностику БМ и ЛІЛ, необходимо учитывать, помимо возраста пораженнюй птицы, инициирования в процентах, нейральных повреждений, пролифераций в сумке и изменений кожи, также наличие отделыных клеточных элементов, принимая во внимание содержание РНК, характер роста и структуру расположения ретикулярных волокон.

\section{References}

BEDNÁŘ, B. - KULHÁNKOVÁ, J.: Podrobnější kriteria elektronmikroskopického rozpoznávání lymfatických a retikulárních buněk. Čsl. patol., 20, 1984: 129-145.

BENDA, V.: Současné možnosti diferenciální diagnostiky leukózy a Markovy nemoci. Proceedings, "Zdravotní problematika hrabavé drůbeže«. Slapská přehrada. CR CSVTS PPP ZS 1984: 92.

BENDA, V. - PETROVSKÝ, E. - MIKULÁŠOVÁ, M.: Sledování mortality a snášky u linií slepic lišících se $\mathrm{v}$ kontaminaci leukemickými viry. Procedings, "14. Česká konference o drůbeži«. Nové Město na Moravě 1987: 68-71.

BIER, O. - SILVA, W. - GÖTZE, D. - MOTA, I.: Základy imunologie. 1. Ed. Praha, Avicenum, 1984, 422 p.

BIGGS, P. M.: Differential diagnosis of avian lymphoid leukosis and Marek's disease. Proceedings of Seminar in the EEC programme for coordination of research on avian leukosis. Copenhagen, Denmark, 12, 1975: 67-85.

HALOUZKA, R.: Kožní forma Markovy choroby. (Thesis) Brno 1981, 114 p.

HOFSTAD, M. - CALNEK, B. - HELMBOLDT, C. - REID, W. - YODER, H.: Diseases of poultry. 7. Ed. Iowa, USA, Iowa State Press AMES 1978, 950 p.

KAADEN, O. - LANGE, S. - STIBUREK, B.: Establishment and characterization of chicken embryo fibroblast clone LSCC-H32. In vitro, 18, 1982: 827-834.

KOŽUŚNÍK, Z.: Zhodnocení zdravotní situace u drủbeže v ČSR v roce 1986. Veterinářství, 37, 1987: 353-354.

LESNIK, F. - HERDA, I. - VRTIAK, O. - HALADEJ, Š.: Informatívny prehlad výskytu Markovej choroby na Slovensku v rokoch 1970-1971. Imunoprofylaxia, 3, 1973: 10-13.

LOJDA, L.: Zhodnocení výskytu nejčastějších onemocnění hrabavé drủbeže v rozmezí let 1975 až 1985. Proceedings, «Zdravotní problematika hrabavé drủbeže«. Slapská přehrada. ČR ĆSVTS PPP ZS 1986: 47.

LOJDA, L. - BÖHM, R.: Praktické zkušenosti v diagnostice Markovy choroby a aviární leukózy. Veterináśství, 34, 1984: 357-359. 
MAAS, H.: Mikroskopische organveranderingen bij Marekse ziekte en lymfoide leukose; enkele opmerkingen betreffende de differential diagnose. Tijdschr. Diergenesk., 99, 1974: 767-789. NEUWIRT, J. - NEČAS, E. - KORNALIK, F. - SULC, K.: Patofyziologie krve. 1. Ed. Praha, Avicenum 1983, 293 p.

PEARSE, E.: Histochemistry. 2. Ed. London, J. a A. Churchill, Ltd. 1960, 962 p.

SICCARDI, J. - BUR MESTER, R.: The differential diagnosis of lymphoid leukosis and Marek's disease. Technical Bulletin No. 1412. Agricultural Research Service, U. S. dep. of agriculture 1970, 26 p.

WOLF, J.: Mikroskopická technika. 1. Ed. Praha, SZdN 1954, 656 p.

YAMAMOTO, H. - YOSHINO, T. - HIHARA, H. - ISHITANI, R.: Histopathologic comparison of Marek's disease with avian lympoid leukosis. Nat. Inst. Anim. Hlth. Quart., 12, 1972: 29-42. 